\title{
15 MAY 1934 COUP D'ÉTAT IN LATVIA: REGULARITY OF DEVELOPMENT OF THE EXISTING PARLIAMENTARY SYSTEM OR A BREAKTHROUGH CALLED BY THE ACTUAL SITUATION. THE VIEW OF THE USA LEGATION IN LATVIA ${ }^{1}$
}

\section{Uldis Krēsliņš}

Dr. hist., Institute of Latvian History, University of Latvia, researcher. Research interests: Latvia's political history of the 20th century.

One of the most contradictorily estimated events in Latvia's 20th century history was the coup d'etat of 15 May 1934. Some researchers consider that the reasons of the coup d'etat are to be found in then existing parliamentary system. They characterised the coup d'etat as a regularity of the development of the existing parliamentary system highlighting the influence of implemented transformations that were realised by the new authoritarian regime of Kārlis Ulmanis. However, the majority of researchers have rejected the view that the flawbacks of the existed parliamentary system were invincible. They have formulated the reasons of the coup d'etat as through the prism of personal ambitions and claims of $\mathrm{K}$. Ulmanis estimating the coup d'etat as a breakthrough in Latvia's political development, which actually was called for by the actual political situation. In the context of these two diverging views it would be useful to acquaint the readers with the opinion of the USA Legation in Latvia on the causes of the coup d'etat on 15 May 1934, which was expressed in two confidential memorandums of the Legation to the USA Secretary of State.

Keywords: Latvia, coup d'etat of 15 May 1934, Kārlis Ulmanis, USA Legation in Latvia, "Riga Boys".

After Lithuania (in 1926) and Estonia (in March 1934) Latvia was the last Baltic state where the institutions of the 
parliamentary democracy were eliminated through the coup détat on 15 May 1934. The person who undertook the role of the inspirer and organiser of the coup détat was Kārlis Ulmanis (1877-1942), a prominent Latvian politician, leader of the Latvian Peasant Union Party and a former Prime Minister, who after the coup détat laid the foundations of an authoritarian regime that existed for the next six years until June 1940, when Latvia was occupied by the Soviet troops.

At that time, the second half of the 1930s, the explanation for the motives that caused the coup d'etat was the same as the one mentioned in 1934 by its organisers: its necessity was determined by an internal threat from some right-wing adventurer groups (the most influential and well-known right-wing radical organisation was the Latvian People's Union "Pērkon,krusts" ("Thunder Cross") founded in $1932^{2}$, but certain threat was also inflicted by the Society of the Cavaliers of the Military Order of Lāčplēsis and Freedom Fighters "Legion", which united the Latvian War of Independence veterans and was headed by Colonel Voldemārs Ozols (1884-1949), who later during the Second World War operated in France as an agent of the Red Army Main Intelligence Directorate), the difficult economic situation, uncertain international situation, but firstly the coup détat was characterised as a regularity of the development of the existing parliamentary system, speaking about refusing from parliamentary democracy as a necessity to save the state from parties' selfish interests and their incessant conflicts. ${ }^{3}$

A different point-of-view appeared when the first memories and first studies about the independent Republic of Latvia were published: written already after the loss of independence in 1940, these works consider the experience of the 1940 and the issue of the responsibility of the authoritarian regime in the loss of independence.

The fact that the authoritarian regime of $\mathrm{K}$. Ulmanis changed the future of the State of Latvia submissively and without ac- 
ceptance of the society (which would have been more difficult from the aspect of legitimacy in case the instutions of parliamentary democracy had continued to exist after $1934^{4}$ ) led to the conseqence that parliamentary democracy had not exhausted all their options, ${ }^{5}$ and the coup détat on 15 May 1934 was a violent breakthrough of parliamentary experience, which was not determined by previous political development.

From that point-of-view a new concept of coup d'état emerged, which was strongly represented in post-war research of former Latvian Social Democrats (Bruno Kalniņš, ${ }^{6}$ Klāvs Lorencs $^{7}$ ). This concept separated the coup détat of 15 May 1934 from the preceding processes of parliamentary democracy; according to this concept, the coup d'état of 15 May 1934 was not a result and final act of the development of parliamentary democracy, but the starting point of a new - authoritarian regime. This concept recognised some failures and shortages of Latvian parliamentarianism, but did not link them with the reasons of the coup détat; ${ }^{8}$ it emphasised the personality of $\mathrm{K}$. Ulmanis and his own political ambitions as the first and the most important reason for the coup d'état. ${ }^{9}$

Both the abovementioned concepts originated in different times, and each had an evident background of interests: while the first concept, which substantiates the necessity of coup d'état as an objective requirement, conformed to the interests of adherents of K. Ulmanis and his regime, the second concept that explained the motives of the coup d'état only with $\mathrm{K}$. Ulmanis political ambition was advantageous to former politicians, and especially, the former leaders of the Latvian Social Democrats, for whom this concept allowed to shake off the responsibility for their policy and political mistakes. However, the diverse views leave a principal question: was the coup d'état on 15 May 1934 a regularity of development of the existed parliamentary system, or was it a breakthrough called only by the actual situation and K. Ulmanis' political ambitions? 
There are two reasons which make the answer to this question extremely important. Firstly, it seems unusual that the Latvian society which spoke about democracy as an undisputable value before the World War and proclaimed the State independence on 18 November 1918, under the slogans of democratic principles, denied their own choice only sixteen years later, and nobody was ready to defend the benefits of democracy. Such a rapid change allowed Latvian post-war emigrants to conclude that Latvians were not ready for democracy at all. ${ }^{10}$ Secondly, it was surprising that exactly $\mathrm{K}$. Ulmanis - the politician who had the biggest merit in the foundation of the State of Latvia and its democracy - became the person who destroyed the Latvian parliamentary system; this contradiction in his political efforts caused essential differences in describing his personality in historical literature - and sometimes these differences are so great that it even seems that these publications are not about one, bet many different people. ${ }^{11}$

When analysing both the abovementioned viewpoints, it is helpful to add one more witness, which is the USA Legation in Latvia. We know that the USA Legation in Riga was one of the most important USA diplomatic centres in Eastern Europe during the interwar period: until 1933, when the USA Government recognised the Soviet Union and opened an Legation in Moscow one year later, the USA Legation in Riga was the closest eyes by which the USA Government monitored the Soviet Union. Several well-known USA diplomats, sometimes called the "Riga Boys", stayed in Latvia during the 1920-1930s. ${ }^{12}$ The most famous of them were Loy Wesley Henderson (18921986), ${ }^{13}$ George F. Kennan (1904-2005) and Charles E. "Chip" Bohlen (1904-1974).

The "godfather" of these "boys" was Robert F. Kelley (18941976), who in 1922 joined the USA State Department, and in 1926 headed the newly created Division of Eastern European Affairs. R. Kelley, who as a USA army officer served in the Bal- 
tic from 1917 to 1922, was an adamant anti-Communist and considered that the State Department needed officers who were fluent in Russian, knew Russian history and Bolshevism's background. In view of this goal, R. Kelly proposed a programme allowing two officers each year to prepare themselves as Russian experts (between 1926 and 1936, R. Kelley selected seven persons for Russian training). ${ }^{14}$ After graduating from the preparatory programme, they went to work for the USA Legation in Riga, where they formulated their views concerning both the Soviet foreign policy objectives and the USA policy towards the USSR.

They shared the conviction that Soviet foreign policy flowed directly from Marxist-Leninist ideology, that the horrors of Stalinist rule within Russia would produce external policies equally totalitarian in purpose. The USSR was a revolutionary state with the foreign policy derived from communist ideology. With such a country the West could never coexist with any success. These views that are known as Riga Axioms in historiography ${ }^{15}$ had a strong influence on the position of the USA Government toward the Soviet Union.

Although Latvia and its policy was not so important and interesting for the USA state interests, the coup d'état of 15 May 1934 was an event that demanded special attention.

THE FIRST MEMORANDUM: “THE FIRST YEAR OF THE ULMANIS REGIME IN LATVIA"

The document in which the reasons for the coup détat were analysed in more detail ${ }^{16}$ was a confidential Memorandum "The First Year of the Ulmanis Regime in Latvia" prepared by the Third Secretary of Legation Mr. George M. Abbott (1904-1988) and sent to the USA Secretary of State Cordell Hull (1871-1955) on 23 August 1935. ${ }^{17}$ The Memorandum had 56 pages and it consisted of five chapters. 
In the beginning the author describes the predisposition of Latvia's situation at the time of the coup d'état and stresses three main aspects: the internal political situation, the economic and financial situation, and finally, the external political situation.

The Memorandum begins with a statement:

"The coup d'etat of May 15, 1934, in order to be correctly understood, must be viewed against the background of political instability which has existed in Latvia from the time of its independence."18

Here the author briefly characterises the formation of Latvian political system and points out a tendency "for every leader to form, or to attempt to form, a political party of his own", that led to a very fragmented system of parties. "Under the system of proportional representation" - the author continues - "most of these various parties were able to obtain at least one or two representatives in the Saeima." Therefore "no one party was strong enough to form a government of its own and the various coalition cabinets formed were nearly always dependant for their existence on the support of some relatively minor party, parties, or individuals." And "as a consequence parliamentary government was extremely unstable." The author of the Memorandum ends his own judgment about Latvia's internal political situation with a statement: "After thirteen years of this situation, the general public was thoroughly disgusted with parliamentary government, in any case as practiced in Latvia." 19

The second aspect - economic and financial situation - is characterised in the Memorandum using the term "critical". The author of the Memorandum devotes special attention to the stability of the national currency system and the specific interests of Latvian farmers. He writes: “... it should be mentioned that the Peasant Union Party and in general all Latvian peasants were, and are, strongly in favour of maintaining the gold standard." 20 By this conclusion the viewpoint of Memorandum differs from the opinions presented by Latvian historians, which usually do not consider the gold standard problem. 
And finally, the third aspect, that is stressed in the Memorandum, is the external political situation. There is one more big difference between the Memorandum and the publications of Latvian historians, which concerns the question about the political sympathies of Latvian Social Democrats. In the mainstream history of the Latvian interwar period it is not accepted to talk about the sympathies of Latvian Social Democrats to Soviet Russia: partly because the communist ideology condemned the Social Democrats as social-chauvinists, ${ }^{21}$ and partly because the former Social Democrats had a strong influence in the circles of Latvian emigrants after the Second World War. The author of the Memorandum was free from these layers, and he writes: "Another factor which also undoubtedly influenced Mr. Ulmanis in his desire to get Latvia's foreign policy out of party politics was the Social Democrats insistence that Latvia establish closer relations with Soviet Russia."22

The author of the Memorandum describes the three abovementioned aspects as the preconditions for the coup détat, while he singles out the debates in the Saeima over the Constitutional Reform Bill as its immediate cause. He writes: "After several months of debate the bill had been so amended that it no longer satisfied the Peasant Union Party. It, moreover, seemed certain that in the final vote on the bill, the Government would be defeated and would have to resign."23

If we try to summarise all of the abovementioned we can conclude that the view of the author of the given Memorandum is closer to the first concept: the author talks about the coup détat of 15 May 1934 as a phenomenon which had objective political and economic preconditions. Of course, this does not mean that the coup détat was unavoidable or welcome: at the night of the coup d'état Latvian Social Democrats were arrested in their bedrooms and, as the author of the Memorandum writes, "as far as is known none of the foreign representatives in Riga were able to give their governments any warning" before 
the coup détat. ${ }^{24}$ However, at the same time, the idea of the necessity of political changes was mature and in that respect the coup détat was expected.

THE SECOND MEMORANDUM: “THE ULMANIS GOVERNMENT IN LATVIA"

Until now the viewpoint and the judgements by which the USA Legation in Latvia interpreted the reasons of the coup détat seems clear. But two years later, in December 1937, the USA Legation in Latvia sent another confidential Memorandum to the USA Secretary of State, prepared by the same George M. Abott, who had by that time become the Second Secretary of the Legation, titled "The Ulmanis Government in Latvia". ${ }^{25}$ And this Memorandum shows a principal difference compared to the Memorandum written two years earlier. The Memorandum begins with an Introduction in which the author briefly summarises the preconditions for the coup d'etat. He repeats the judgements about "extremely advanced Latvian constitution", "short-lived coalition governments", and adds: "Another factor was undoubtedly the personal ambition and desire for power of Dr. Ulmanis, which were encouraged by political developments in Germany and Estonia in 1933 and early 1934."26 This opinion seems unexpected: in the previous Memorandum the personal ambition of K. Ulmanis was not even mentioned, and suddenly, two years later, it was stressed as one of the most important factors! What had happened? It is clear that the real reasons for the coup détat had not changed during these two years. The only change was the attitude to $\mathrm{K}$. Ulmanis and motives of his political activity during his authoritarian regime. During the two years between both Memorandums, from 1935 to 1937, the Prime Minister K. Ulmanis had become the President of the State, the cult of him as the "Land Host" was growing and becoming stronger, and any opposition leaders or newspapers 
were silenced. All these processes provided strong evidence about the personal ambitions of K. Ulmanis, but it was evidence post factum, evidence that referred to K. Ulmanis as the "Land Host" after the coup d'état, and not before.

Hence, in this case we can talk about some kind of transposition, when a future experience would be transposed to events and processes that had happened earlier.

\section{CONCLUSIONS}

Both of the abovementioned confidential Memorandums prepared by the USA Legation in Latvia characterised the coup d'etat of 15 May 1934 as a phenomenon which had objective political and economic preconditions, and in this respect it may be possible to affirm that the coup d'état was a regularity of the development of the existing parliamentary system. Moreover: both Memorandums clearly indicate the disadvantages of the Latvian parliamentary system as one of the reasons of the coup d'etate. The importance of this recognition in this case is not in its content but rather in its author: in Latvian historiography, with some exceptions, under the influence of Social Democrats and due to ideological circumstances the faults of the Latvian parliamentary system were not recognised as the reason of the coup d'etat, and the judgements about the flaws of the Latvian parliamentary system were usually linked to the slogans of anti-democrats or apologists of $\mathrm{K}$. Ulmanis authoritarian regime. Both Memorandums of the USA Legation show that this is not correct.

There is a more complicated question: can we talk about the personal ambitions of $\mathrm{K}$. Ulmanis as the reason for the coup d'état? The abovementioned confidential Memorandums gives two opposing answers: the Memorandum of the 1935 says: No! - while the Memorandum of the 1937 says: Yes! The stumbling stone, I assume, is not only in the transposition of 
some later experience, but also in overlapping of two different points of view that should be separated.

If we say that K. Ulmanis was a destroyer of the Latvian parliamentary democracy, it is an indisputable truth. It would be safe to say that if $\mathrm{K}$. Ulmanis did not organize the coup d'état on 15 May then the parliamentary system would continue to exist at least until May 16. But it does not mean that in this decision $\mathrm{K}$. Ulmanis was guided only by his own personal ambitions.

At first, it is necessary to remember that K. Ulmanis was one of the founders of the Latvian State and Latvia's first Prime Minister in 1918; in this context it would be weird to allow that his personal ambitions waited for the next sixteen years until 1934, when K. Ulmanis was fifty-six years old. And secondly, K. Ulmanis was a pragmatic politician with considerable experience, and he would not have decided to "pass the Rubicon" if he was not sure that the society was ready to accept political changes. In this situation we can say that the views of the society conform to K. Ulmanis' personal ambitions, but not more.

Finally, I would like to quote a conclusion from the covering letter by which the confidential Memorandum in 1935 was presented. The author of this covering letter was Felix Cole (18871969) - USA Legation Charge d'Affaires ad interim. He wrote:

"In enumerating the accomplishments of the Ulmanis regime during its first year, one cannot fail to be impressed by their magnitude and, although one may not sympathize with the methods followed or the objects in view, it must be admitted that both internally and externally Latvia is in a considerably stronger and more stable position than on May 15, 1934." ${ }^{27}$

\section{REFERENCES AND NOTES}

1 The article is based on a report that was read at Conference on Baltic Studies in Riga “The Baltic states at 99: Past, Present and Future”, 19-21 June 2017. The author thanks the colleagues Dr. habil. hist. Valdis Bērziņš and Elina Pētersone-Gordina, who helped to prepare the article. 
2 See: Vincent E. McHale (1986). The Party Systems of the Baltic States: A Comparative European Perspective. Journal of Baltic Studies, XVII (4), pp. 295-312.

3 See: Ernests Blanks (1935). Vadonis un vadonības laiks: 15. maija domas. Rīga: Autora izdevums, pp. 3-7. See also: Žanis Unāms (1953). Laiku atspulgā. Oldenburga: Loga apgāds, pp. 8-10; Edvards Virza (1955). Kārlis Ulmanis. Kopenhāgena: Imanta, pp. 134-158; Alfreds Bērziņš (1973). Kārlis Ulmanis: cilvēks un valstsvīrs. B.v.: Grāmatu Draugs, pp. 162-207.

4 If the Saeima (Latvia's parliament) would continue to work until 1940, the state attitude towards the introduction of Soviet troops in Latvia would be formulated by the Saeima, and it would be harder from its one hundred deputies to obtain unanimous approval for the arrival of "friendly" troops to Latvia, see: Miķelis Valters (1951). 15. maija apvērsums un ārkārtējās pilnvaras. Stockholm: Jaunās Latvijas apgāds, pp. 42-45; Jānis Stradiṇš (1998). Kārlis Ulmanis - valstsvīra liktenis un mācības. In: Andris Caune (ed.). Kārlim Ulmanim 120. Rīga: LVI apgāds, pp. 15-28, here pp. 21-22; Arturs Žvinklis (2010). No autoritārisma līdz padomju totalitārismam: manipulācijas ar Latvijas Republikas Satversmi (1934-1940). In: Jānis Bērziņš (ed.). Latvijas valstiskumam 90. Latvijas valsts neatkarïba: ideja un reali$z \bar{a} c i j a$. Rīga: LVI apgāds, pp. 223-239.

5 Ādolfs Šilde (1991). Latviešu demokrātija. In: Ādolfs Šilde. Trimdinieka raksti: 1944-1990. Minstere: Apgāds Latvija, pp. 66-67; Andrievs Ezergailis (1990). Ulmanis un ulmanisms. Literatūra un Māksla, 1. septembris, pp. 5, 10.

6 Bruno Kalniņš (1993). Latvijas Sociāldemokratijas 50 gadi (1904-1954). Stokholma: Memento.

7 [Klāvs Lorencs] (2005). Kāda cilvēka dzīve: Klāva Lorenca atminas. Rīga: Zelta grauds.

8 "Satversmes kritika ir populārs, bet maz pārliecinošs apvērsuma apologèètu arguments" ["The critique of the Satversme is a popular, but little convincing argument used by apologists of the coup détat"], see: Aivars Stranga (1994). LSDSP un 1934. gada 15. maija apvērsums. Demokrātijas likteñi Latvijā. Rīga: Preses nams, p. 11.

9 See: Edgars Dunsdorfs (1978). Kārḷa Ulmaņa dzīve: cel̦inieks, politiķis, diktators, moceklis. Stockholm: Daugava, pp. 268-270, 344-346; Mārtiņš Virsis (1990). Apvērsuma priekšvakarā. In: Pretstatu cīnā. Latvija 1917.-1950: Krājums. Rīga: Avots, pp. 176-184; Valters Ščerbinskis (2012). 1934. gada 15. maija apvērsums: cēloṇi, norise un sekas. In: Valters Ščerbinskis, Ēriks Jēkabsons (eds.). Apvērsums: 1934. gada 15. maija notikumi avotos un pētījumos. Rīga: Latvijas Nacionālais arhīvs, pp. 9-57, here p. 19.

10 See: Šilde. Latviešu demokrātija. In: Šilde. Trimdinieka raksti: 1944-1990, p. 69. 
11 This phenomenon of "divided" K. Ulmanis in historiography is clearly illustrated by an article by Jānis Stradiņš, titled “18. November's Ulmanis”, see: Jānis Stradiņš (2003). 18. novembra Ulmanis (Latvijas Republikas pirmais Ministru prezidents). In: Andris Caune (ed.). Kārlim Ulmanim 125. Rīga: LVI apgāds, pp. 14-35.

12 Donald E. Davis, Eugene P. Trani (2009). Distorted Mirrors: Americans and Their Relations with Russia and China in the Twentieth Century. Columbia: University of Missouri Press, pp. 34-40.

13 Loy W. Henderson was one of the authors to the Welles Declaration of 1940, which established USA non recognition policy of Baltic States occupation by Soviet Union.

14 Davis, Trani. Distorted Mirrors, pp. 36-38.

15 Daniel Yergin (1977). Shattered Peace: The Origins of the Cold War and the National Security State. Boston: Houghton Mifflin Company.

16 First telegrams and reports send by the USA Legation in Riga to the USA Secretary of State immediately after the coup d'etat (the texts of these telegrams and reports are published in the collection of documents devoted to the 1934 coup d'etat, see: Ščerbinskis, Jēkabsons (eds.). Apvērsums: 1934. gada 15. maija notikumi avotos un pètījumos, pp. 395-401) informed about the process and circumstances of the coup d'etat and made preliminary judgments about the development of future processes, without giving the more comprehensive analysis of the causes of the coup d'etat.

17 George M. Abbott (1935). Confidential Memorandum "The First Year of the Ulmanis Regime in Latvia”. National Archives (USA), Microfilm 1177, Roll 8, File 860P.00/196, pp. 1-56.

Ibid., p. 1.

Ibid., p. 3.

Ibid., p. 4.

21 R. Uyska (1932). Fashizm i sotsial-fashizm v sovremennoi Latvii [Fascism and Social Fascism in Modern Latvia]. Moskva; Leningrad: Partiinoe izdatel'stvo.

22 George M. Abbott (1935). Confidential Memorandum "The First Year of the Ulmanis Regime in Latvia”. National Archives (USA), Microfilm 1177, Roll 8, File 860P.00/196, p. 5.

23 Ibid., p. 6.

24 Ibid.

25 George M. Abbott (1937). Confidential Memorandum “The Ulmanis Government in Latvia”. National Archives (USA), Microfilm 1177, Roll 8, File 860P.00/219, pp. $1-70$.

26 Ibid., p. 1.

27 Felix Cole (1935). Covering letter of the Confidential Memorandum addressed to USA Secretary of State. National Archives (USA), Microfilm 1177, Roll 8, File 860P.00/196, pp. 2-3. 


\section{GADA 15. MAIJA APVĒRSUMS LATVIJĀ: PASTĀVOŠĀS PARLAMENTĀRĀS SISTĒMAS ATTĪSTİBAS LIKUMSAKARĪBA VAI AKTUĀLĀS SITUĀCIJAS IZSAUKTS PĀRRĀVUMS. ASV SÜTNIECĪBAS LATVIJĀ SKATİJUMS}

\section{Uldis Krēsliņ̌̌}

Dr. hist., Latvijas Universitātes Latvijas vēstures institūta pētnieks. Zinātniskās intereses: Latvijas 20. gadsimta politiskā vēsture.

Viens no diskutablākajiem un pretrunīgāk vērtētajiem Latvijas 20. gadsimta vēstures notikumiem ir 1934. gada 15. maija apvērsums. Vairāki pētnieki tā cēloṇus saista ar Latvijas parlamentārās sistēmas nepilnībām. Viṇi raksturo apvērsumu kā pastāvošās parlamentārās iekārtas attīstības likumsakarību un uzsver Kārḷa Ulmaṇa autoritārā režìma īstenoto pārmaiṇu labvēlīgo ietekmi uz valsts attīstību. Tomēr pētnieku lielākā daḷa noraida uzskatu, ka Latvijas parlamentārās iekārtas trūkumi bija nepārvarami. Viṇi apvērsuma cēloṇus analizē caur K. Ulmaņa personīgo ambīciju prizmu un vērtē apvērsumu kā konkrētās politiskās situācijas izsauktu pārrāvumu Latvijas politiskajā attīstībā. Šo divu atšķirīgo apvērsuma cēloṇu skaidrojumu kontekstā ir lietderīgi iepazīties ar ASV sūtniecības Latvijā skatījumu uz 1934. gada apvērsuma cēloṇiem, kas ir izteikts divos sūtniecības sagatavotos konfidenciālos memorandos ASV Valsts sekretāram.

Atslēgas vārdi: Latvija, 1934. gada 15. maija apvērsums, Kārlis Ulmanis, ASV vēstniecība Latvijā, "Riga Boys".

\section{Kopsavilkums}

Viens no Latvijas historiogrāfijā pretrunīgāk vērtētiem 20. gadsimta vēstures notikumiem ir Kārḷa Ulmaṇa īstenotais 1934. gada 15. maija apvērsums, kas apturēja valsts demokrātisko institūtu darbību un ievadīja K. Ulmaṇa autoritārā režīma posmu. Sākotnēji, 30. gadu otrajā pusē, literatūrā minētais apvērsuma cēloṇu skaidrojums palika vien pašu apvērsuma rīkotāju dotā pamatojuma ietvaros, apzīmējot to kā likumsakarīgu neveiksmīgās parlamentārisma pieredzes noslēgumu un runājot par atteikšanos no parlamentārās iekārtas kā nepieciešamu un sabiedrības noskaņojumos izjustu lēmumu, lai izrautu valsti no partiju savtīgo interešu purva. Jauns skatījums sāka veidoties brīdī, kad parādījās pirmās laikabiedru atmiņas un pirmie pētījumi par Latvijas valsts neatkarības posmu: sarakstīti jau pēc valsts neatkarības zaudēšanas 1940. gadā, šie darbi spriedumos par 1934. gada apvērsumu nevarēja neievērot 1940. gada 
pieredzi un jautājumu par K. Ulmaņa režīma lomu valsts neatkarības zaudēšanā. Tā kā autoritārais režīms bija padevīgi un bez sabiedrības akcepta izškīiris valsts likteni 1940. gadā, kas gadījumā, ja turpinātu pastāvēt 1934. gadā likvidētie tautas pārstāvniecības institūti, vismaz no leg̣itimitātes aspekta būtu bijis apgrūtinošāk, tad no šì skatījuma izauga logiska konsekvence: lai arī Latvijas parlamentārisma laikmetam bija savas neveiksmes un nepilnības, parlamentārā iekārta tomēr nebija izsmēlusi visas savas iespējas, un 1934. gada apvērsums bija vardarbīgs šīs parlamentārisma pieredzes pārrāvums, varas akts, kas neizrietēja no iepriekšèjās valsts politiskās attīstības. Tā pakāpeniski nostiprinājās uzskats, kas visspilgtāk atklājas Latvijas kreiso sociāldemokrātu tradīcijā rakstītajos darbos (Bruno Kalniņš, Klāvs Lorencs) un kas veido šķirtni un nodala līdz 1934. gadam pastāvošās parlamentārās iekārtas procesus no 1934. gada apvērsuma. Šis skatījums nenoliedz parlamentārās iekārtas trūkumus, taču tie netiek tieši saistīti ar 1934. gada apvērsumu, paliekot vien kā laikmeta fons, kamēr apvērsuma cēloṇu skaidrojumā tas priekšplānā izvirza paša K. Ulmaṇa personiskos motīvus un vispārējās laikmeta situācijas nosacījumus.

Šo divu atšķirīgo skatījumu kontekstā ir lietderīgi iepazīties ar kāda neitrāla vērotāja spriedumiem, kas šajā gadījumā izteikti divos ASV sūtniecības Latvijā sagatavotos konfidenciālos memorandos ASV Valsts sekretāram. Pirmais no tiem - 1935. gadā sastādītais memorands "Ulmaṇa režīma pirmais gads Latvijā” - kā apvērsuma priekšnoteikumus iztirzāja trīs aspektus: Latvijas iekšpolitisko situāciju, ekonomisko un finansiālo situāciju un ārpolitisko situāciju. Aprakstot iekšpolitisko situāciju līdz apvērsumam, atzīmēts Latvijas parlamenta sadrumstalotais sastāvs un kā tā sekas ḷoti nestabilās koalīcijas valdības. Latvijas ekonomiskā un finansiālā situācija memorandā raksturota kā "kritiska", atsevišķi atzīmējot Latviešu zemnieku savienības un zemnieku vispār nostāju par zelta standarta saglabāšanu. Savukārt ārpolitiskās situācijas aprakstā minēts kāds Latvijas vēsturnieku darbos apiets aspekts - Latvijas sociāldemokrātu kurss uz ciešāku attiecību veidošanu ar Padomju Krieviju. Tikmēr kā apstāklis, kas deva izšķirošo grūdienu apvērsuma īstenošanai, memorandā izceltas vairākus mēnešus ilgušās parlamenta debates par Satversmes reformu, kas draudēja noslēgties bez rezultāta. Viss minētais ḷauj secināt, ka memoranda autora viedoklis bija tuvāks pirmajam no abiem skatījumiem, norādot, ka 1934. gada apvērsumam bija objektīvi politiskie un saimnieciskie priekšnoteikumi.

Taču divus gadus vēlāk, 1937. gada decembrī, ASV sūtniecība Latvijā nosūtīja ASV Valsts sekretāram vēl vienu memorandu "Ulmaņa valdība 
Latvijā", kurā bija kāda principiāla atšķirība: vēlreiz uzskaitot 1934. gada 15. maija apvērsuma cēloṇus, līdzās jau iepriekš minētajiem memorandā kā vēl viens faktors atzīmētas K. Ulmaņa personiskās ambīcijas un varaskāre. Šis apgalvojums šḳiet negaidīts: 1935. gadā sastādītajā memorandā K. Ulmaṇa personiskās ambīcijas netika pat pieminētas, bet pēc diviem gadiem tās izceltas kā viens no apvērsuma cēloņiem. Kā var izskaidrot šo pārmaiņu? Ir skaidrs, ka šo divu gadu laikā paši apvērsuma cēloṇi nebija mainījušies. Vienīgais, kas bija mainījies, bija attieksme pret K. Ulmani un viṇa îstenoto autoritārā režīma politiku, kurā būtisku vietu ieṇēma K. Ulmaņa kā "zemes saimnieka" kults un visu režìma politisko oponentu apklusināšana. Tā bija liecība K. Ulmaṇa personiskajām ambīcijām, taču tā bija liecība post factum, liecība par K. Ulmani kā "zemes saimnieku" jau pēc apvērsuma, nevis pirms tā.

Lai gan abu ASV sūtniecības Latvijā sagatavoto memorandu viedoklis par K. Ulmaņa personiskajām ambīcijām kā vienu no 1934. gada 15. maija apvērsuma cēloṇiem atšķiras, tie abi norāda, ka apvērsumam bija objektīvi politiskie un ekonomiskie priekšnoteikumi, to skaitā Latvijas parlamentārās demokrātijas nepilnības. Šis atzinums ir pietiekami autoritatīvs un nozīmīgs, lai to iekḷautu Latvijas historiogrāfijā izvērstajā neklātienes diskusijā par 1934. gada 15. maija apvērsuma cēloṇiem, kurā viens no viedokḷiem ir uzskats, ka Latvijas parlamentārās sistēmas nepilnības bija tikai atruna, nevis viens no 1934. gada apvērsuma cēloņiem, un visus spriedumus par Latvijas parlamentārisma trūkumiem tas traktē kā antidemokrātu un K. Ulmaņa režīma apologeètu viedokli. Abi minētie ASV sūtniecības Latvijā sagatavotie memorandi parāda, ka šāds traktējums nav korekts. 